\title{
Response of Monodehydroascorbate Reductase in Lettuce Leaves Subjected to Low Temperature Stress
}

\author{
Sang-Jae Kang* \\ School of Applied Ecological Resources, Kyungpook National University, Sangju 742-711, Korea
}

Received November 5, 2010 /Accepted March 16, 2011

\begin{abstract}
The relationship between MDHA reductase activity and ascorbate, dehydroascorbate, and hydrogen peroxide content was evaluated, and this experiment was conducted to determine the change of MDHA reductase activity and the level of steady-state mRNA abundance of MDHA reductase in lettuce leaves subjected to low temperature stress. MDHA reductase activity of chloroplastic and cytosolic fraction in lettuce leaves subjected to $4^{\circ} \mathrm{C}$ for $24 \mathrm{hr}$ increased, followed by a steady decrease during the duration of recovery to $20^{\circ} \mathrm{C}$ for $48 \mathrm{hr}$. The content of ascorbate slowly increased during low temperature treatment, followed by a rapid increase during the duration of recovery to $20^{\circ} \mathrm{C}$ for 48 $\mathrm{hr}$, while dehydroascorbate content rapidly decreased. The relationship between MDHA reductase activity of chloroplastic and cytosolic fraction in lettuce leaves subjected to $4^{\circ} \mathrm{C}$ and ascorbate content correlated positively $\left(\mathrm{R}^{2}=0.9240,0.9108\right.$, respectively), but MDHA reductase activity of chloroplastic and cytosolic fraction and dehydroascorbate were reversely correlated $\left(\mathrm{R}^{2}=0.8638,0.8980\right.$, respectively). Hydrogen peroxide content and MDHA reductase activity of chloroplastic and cytosolic fraction in lettuce leaves subjected to $4^{\circ} \mathrm{C}$ correlated positively $\left(\mathrm{R}^{2}=0.9443,0.9647\right.$, respectively). Northern blot analysis showed that the level of mRNA transcript of MDHA reductase was similar to total activity of MDHA reductase, and also that the level of mRNA of MDHA reductase after recovery to $20^{\circ} \mathrm{C}$ for $24 \mathrm{hr}$ decreased.
\end{abstract}

Key words : Ascorbate, dehydroascorbate, hydrogen peroxide, MDHA reductase

\section{서 론}

저온에 노출된 식물에서도 산화적 스트레스를 받아 활성산 소인 수퍼옥사이드 $\left(\cdot \mathrm{O}_{2}^{-}\right)$가 생성되므로 수퍼옥사이드 전이 효소(Superoxide dismutase, SOD)가 다른 활성 산소종인 과 산화수소로 환원시키는 효소적작용이 일어나며, 이 과정에서 생성된 과산화수소는 아스코브산(Ascorbate, ASC)의 항산화 작용과 관련된 일련의 효소적과정으로 물로 환원되면서 무독 화된다[2,17]. 이 효소적 과정은 아스코브산이 전자공여체로 작용하고 아스코브산 과산화효소(Ascorbate peroxidase, APX) 가 촉매하는 반응으로 일어나며 이 과정에서 아스코브산은 모 노디하이드로아스코브산(Monodehydroascorbate, MDHA)으 로 환원된다[2,9,19,25]. 아스코브산 과산화효소에 의한 효소적 과정의 중간생성물인 $\mathrm{MDHA}$ 는 $\mathrm{NADH}$ 를 전자공여체로 하여 $\mathrm{MDHA}$ 환원효소( $\mathrm{MDHA}$ reductase)의 작용을 받아 아스코브 산으로 직접 재생되거나, 비효소적 과정으로 디하이드로아스 코브산(Dehydroascorbate, DHA)으로 환원된다. 이 과정에서 $\mathrm{MDHA}$ 환원효소는 활성 산소종인 과산화수소의 제거 과정에 일차적인 역할을 하는 것으로 잘 알려져 있으며, 세포 내 아스 코브산의 수준을 일정하게 유지하는 데 매우 중요한 역할을

*Corresponding author

Tel : +82-54-530-1231, Fax : +82-54-530-1239

E-mail:kangsj@knu.ac.kr
하는 효소이다[9,25]. MDHA 환원효소는 dehydroascorbate reductase (DHAR)의 작용과 적절한 네트워크로 연결되어 있 는 항산화효소이며[2,8], 이 효소의 활성은 엽록체뿐 만 아니라 사이토졸, 마이토콘드리아 등에서도 발현된다고 알려져 있다 [18].

$\mathrm{MDHA}$ 환원효소의 활성도 변화는 수분부족[13,16], 오존 [14], 과산화수소 처리[27] 등에서 확인되었으며, 상추[12,13], 오이[14,15], 대두[16], 시금치[21], 배추[27] 등의 여러 식물종 에서 나타난다고 보고되어 있다. 또한 시금치 엽록체에서 분 리한 $\mathrm{MDHA}$ 환원효소의 정제와 $\mathrm{cDNA}$ 를 클로닝하여 그 특성 을 보고한 바 있으며[18,20,23], 완두콩에 존재하는 $\mathrm{MDHA}$ 환 원효소의 $\mathrm{cDNA}$ 를 클로닝하여 여러 가지 스트레스에 반응하 는 $\mathrm{MDHA}$ 환원효소의 활성과 단백질발현, $\mathrm{mRNA}$ 수준 등을 보고한 바에 의하면 연속적 광조사, 강한 광, 연속된 암조건, 물리적 손상, 저온, 고온, 제초제, 카드뮴 등에 노출시킨 잎에 서 $\mathrm{MDHA}$ 환원효소의 활성도의 변화가 있음이 보고되어 있 다[18,20]. 저온처리한 상추의 잎 내에서 아스코브산 과산화효 소와 DHA 환원효소와의 일련의 효소적작용과 비효소적 항산 화작용과 관련된 요인들과의 관련성과 항산화효소의 활성도 와 이 효소들의 $\mathrm{mRNA}$ 의 수준은 밀접하게 연관되어 있음을 보고하였다[12]. 식물체의 저온스트레스의 적응성과 관련된 항산화효소의 변화는 주로 SOD, 카탈레이스(Catalase), APX, 글루타싸이온 환원효소(Glutathione reductase, GR) 등과 연 
관된 작용으로 보고[11,17]되어 있으나, $\mathrm{MDHA}$ 환원효소의 작 용과의 관련성을 보고한 결과는 거의 없는 실정이이다. 따라 서 본 연구에서는 정상적으로 생육하고 있는 상추식물을 저온 에 노출시킨 후 과산화수소의 독성을 제거하는 항산화물질인 아스코브산과 일련의 효소적과정 중에 작용하는 $\mathrm{MDHA}$ 환원 효소와의 연관성을 확인하여 식물체의 저온 적응성에 대한 기초자료를 얻기 위하여 수행하였다.

\section{재료 및 방법}

\section{공시작물의 생육 및 저온 처리}

상추(Lactuca Sativa L. cv. Baronet, Journey Co. USA)를 공 시작물로 하여 전보[12]와 같은 생육조건 하에서 생육시켰다. 4 주간 생육시킨 공시작물을 $4^{\circ} \mathrm{C}$ 로 조절된 암상태의 생장상에 서 24시간 동안 저온처리 하였으며, 분석용 잎 시료는 처리 시간별 $(0,3,6,12,24$ 시간째 $)$ 로 채취하였다. 저온 처리 한 후 공시작물을 최적 생육온도 $\left(20^{\circ} \mathrm{C}\right)$ 에서 회복시켰으며, 회복 처 리 시간별(24, 48시간)로 각각 분석용 잎 시료를 채취하고 즉시 액체질소에 담가 동결한 후 저온냉동고 $\left(-70^{\circ} \mathrm{C}\right)$ 에 보관하면서 실험에 사용하였다.

\section{조효소액의 조제 및 MDHAR 활성도 측정}

$\mathrm{MDHA}$ 환원효소의 활성도 측정을 위한 조효소액은 Hossaine 등[9]과 Jiménez 등[10]의 방법을 혼용하여 조제하였 다. 시료 $(1 \mathrm{~g})$ 를 액체질소를 넣고 마쇄한 후 10 배 부피의 추출 액(100 mM 인산완충액, $\mathrm{pH} 7.5,1 \mathrm{mM}$ EDTA, $0.33 \mathrm{M}$ Mannitol, $1.0 \%$ (w/v) PVP-40, $1 \mathrm{mM}$ PMSF)을 첨가하여 현탁 하였다. 현탁액을 두겹의 miracloth로 거른 다음 2,200× $g$ 에서 5 분간 원심분리하여 수집한 침전물을 엽록체분획 (Chloroplastic fraction)으로 하였다. 상징액은 $15,000 \times g$ 로 원 심분리하여 침전물을 제거하고 수집한 상징액을 세포질분획 (Cytosolic fraction)으로 하였다. 각 분획 조효소액의 단백질 함량은 Bradford [3]의 방법으로 측정하였다. $\mathrm{MDHA}$ 환원효 소의 활성도 측정은 Hossain 등[9]의 방법을 약간 변형하여 다음과 같이 측정하였다. 일정량 $(50 \mu l)$ 의 조효소액과 반응용 액[50 mM 인산완충액(pH7.6), $0.3 \mathrm{mM} \mathrm{NADH,} 2.5 \mathrm{mM}$ ascorbate]을 최종부피가 $1 \mathrm{ml}$ 가 되도록 혼합하였다. 이 반응 용액에 0.5 unit의 ascorbate oxidase (Sigma사)를 넣어 반응을 개시하였으며, $\mathrm{NADH}$ 의 산화정도 $\left(\varepsilon=6,200 \mu \mathrm{M}^{-1} \mathrm{~cm}^{-1}\right)$ 를 340 $\mathrm{nm}$ 에서 1 분 동안 흡광도 변화를 측정하고 감소된 흡광도를 효소의 활성도로 계산하여 나타내었다.

\section{과산화수소의 함량}

과산화수소의 함량의 측정은 시료 $0.5 \mathrm{~g}$ 을 액체질소를 넣고 마쇄한 후 10배 부피의 $0.1 \%(\mathrm{w} / \mathrm{v})$ trichloroacetic acid (TCA) 로 현탁하여 추출하고 원심분리 $(12,000 \times \mathrm{g}, 15$ 분 $)$ 하였다. 상징
액을 $10 \mathrm{mM}$ 인산완충액 $(\mathrm{pH}$ 7.0)과 $1 \mathrm{M} \mathrm{KI}$ 를 첨가하여 발색시 킨 후 $390 \mathrm{~nm}$ 에서 흡광도를 측정하고 표준곡선에 의해 과산화 수소의 함량을 $\mu \mathrm{mol} \cdot \mathrm{gfw}^{-1}$ 단위로 환산하였다[1,6].

\section{아스코브산과 디하이드로아스코브산의 함량}

아스코브산과 디하이드로아스코브산 함량의 측정은 Foyer 등[5]과 Yoshimura 등[26]의 방법을 혼용하여 사용하였다. 시 료 $(0.5 \mathrm{~g})$ 를 액체질소를 넣고 마쇄한 후 10 배 부피의 $6 \%(\mathrm{v} / \mathrm{v})$ $\mathrm{HClO}_{4}$ 용액으로 추출한 후 $12,000 \times g$ 에서 원심분리하였다. 아스코브산의 함량은 수집한 상징액을 인산완충액 $(\mathrm{pH} 12.7)$ 으로 10 배 희석한 직 후 $265 \mathrm{~nm}$ 에서 흡광도를 측정하고, 동일 한 상징액에 아스코브산 산화효소(ascorbate oxidase 5 units) 를 첨가하고 동일한 파장에서 측정한 흡광도 차이를 표준곡선 에 의하여 계산하여 측정하였다. 디하이드로아스코브산의 함 량은 총 아스코브산의 함량에서 아스코브산의 함량을 뺀 값으 로 나타내었다. 총 아스코브산의 함량은 추출액 $1 \mathrm{ml}$ 에 1.2 $\mathrm{M} \mathrm{K}_{2} \mathrm{CO}_{3}$ 를 첨가하여 최종 $\mathrm{pH}$ 를 6.0 으로 조정한 반응액에 10 $\mathrm{mM}$ dithiothreitol (DTT)을 넣고 $25^{\circ} \mathrm{C}$ 에서 10 분간 반응시켜 아스코브산의 측정방법과 동일하게 측정하였으며 각각의 함 량은 $\mu \mathrm{mol} \cdot \mathrm{gfw}^{-1}$ 단위로 나타내었다.

\section{총 RNA 추출 및 Northern Blot}

총 RNA의 분리는 Chang 등[4]의 방법을 약간 수정한 $\mathrm{CTAB}$ 완충액( $2 \% \mathrm{CTAB}, 100 \mathrm{mM}$ Tris, $\mathrm{pH}$ 8.0, $20 \mathrm{mM} \mathrm{EDTA}$, $1.4 \mathrm{M} \mathrm{NaCl})$ 을 사용하여 분리하였다. 총 RNA $(11.4 \mu \mathrm{gg})$ 는 $1.5 \%$ (w/v) agarose 젤[ $1 \times$ MOPS (20 mM $N$-morpholino) propanesulfonic acid, pH 7.0), $2 \mathrm{mM} \mathrm{Na-acetate,} 1 \mathrm{mM}$ EDTA, $3.7 \%$ (v/v) formaldehyde)에서 전기영동한 후 Sambrook 등[22]의 방법을 약간 수정하여 20배의 SSC 용액에 서 membrane에 전이시켰다.

Monodehydroascorbate 환원효소의 cDNA는 시금치의 cDNA (accession. No. AB063289)로부터 프라이머 제작 프 로그램(Primer3, Whitehead Institute, USA)을 사용하여 프 라이머[MDHAR: 5'-CAT TTT GTC CAA TTC TCC AT-3' (F), 5'- TCC TCA TTT TCT CTT TCC AA-3' (R)]를 제작하 여 전보[12,13]와 동일한 조건에서 $\mathrm{PCR}$ 을 수행하였다. 증폭 시킨 DNA단편을 주형으로 하여 random primer DNA 표 지 프로토콜을 사용하여 $\left[\mathrm{a}^{32} \mathrm{P}\right] \mathrm{dCTP}(50 \mu \mathrm{Ci} / \mathrm{ml})$ 로 표지하 였으며 Northern blot분석은 전보[12]와 동일한 방법으로 수 행하였다.

\section{결과 및 고찰}

\section{$\mathrm{MDHA}$ 환원효소의 활성도변화}

$4^{\circ} \mathrm{C}$ 의 저온에 24 시간 노출시킨 상추의 잎 내에서 아스코스 산의 재생과 관련된 $\mathrm{MDHA}$ 환원효소(MDHAR)의 활성도는 
엽록체분획과 세포질분획에서 추출하여 측정하였으며 그 활 성도 변화는 Fig. 1과 같다.

Fig. 1에 나타난 바와 같이 $\mathrm{MDHA}$ 환원효소의 활성도 변화 는 저온에 노출되는 시간이 길어질수록 활성도가 증가하였으 며, 특히 저온에 노출된 시간이 6시간이 지나면서 급격하게 증가하는 경향을 보였다. 엽록체분획과 세포질분획에서 동일 한 경향을 보이며 실온으로 회복시켰을 때 $\mathrm{MDHA}$ 환원효소 의 활성도가 감소하는 경향을 보였다. 전보[12]에서 식물이 저 온과 같은 스트레스에 노출되면 산화적 스트레스가 증가하게 되고 이때 생성되는 과산화수소를 제거하기 위한 메카니즘을 가지고 있다. 아스코브산을 전자공여체로 사용하는 아스코브 산 과산화효소(APX)와 DHA 환원효소(DHAR)의 활성이 급 격하게 증가하는 것으로 나타났다. 이와 이[17]는 오이의 잎에 서 저온 처리를 함으로써 과산화수소의 함량이 증가하고, 수 퍼옥사이드 전이효소(SOD)의 활성도도 증가한다고 보고하였 다. 그러나 $25^{\circ} \mathrm{C}$ 로 회복시키면 수퍼옥사이드 전이효소의 활성 도는 회복되지만 과산화수소의 함량은 상당히 증가한다고 하 였다. 이 결과는 저온스트레스가 오이식물에 대한 산화적스트
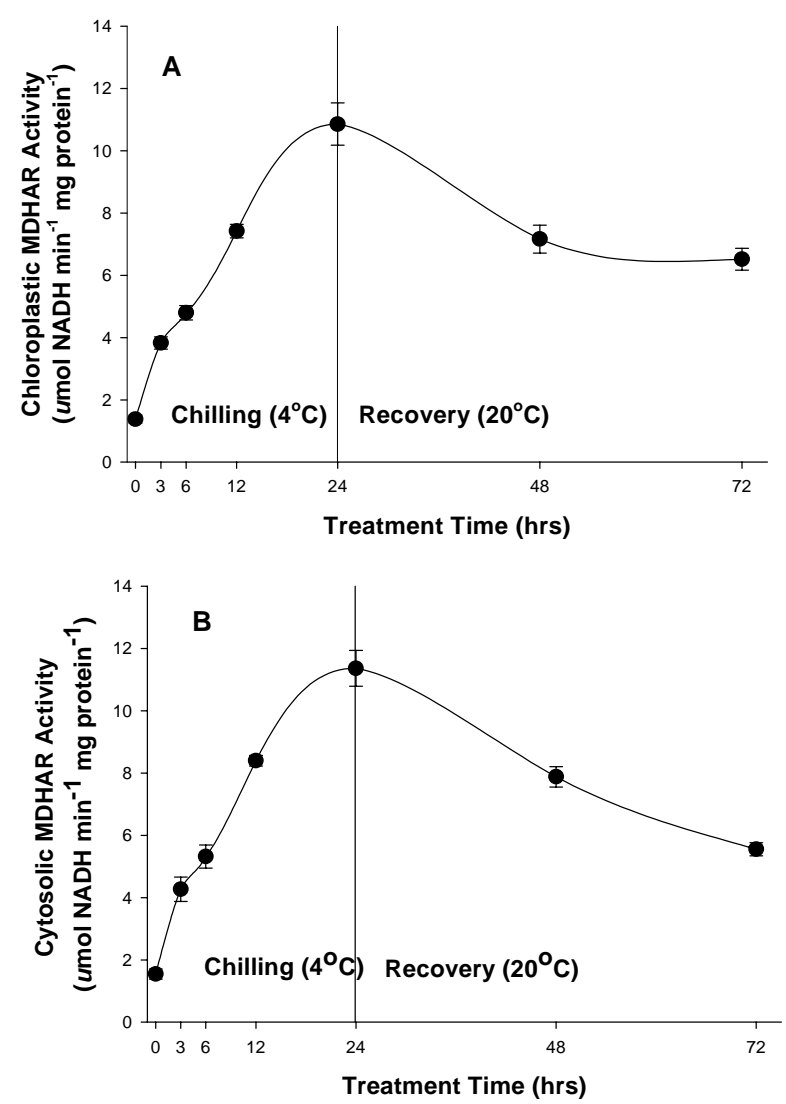

Fig. 1. Changes of chloroplastic (A) and cytosolic MDHA reductase (MDHAR) activity (B) in lettuce leaves as subjected to low temperature stress. Cold treatments were performed at $4^{\circ} \mathrm{C}$ for $24 \mathrm{hr}$, and followed by recovery was performed at $20^{\circ} \mathrm{C}$ for $48 \mathrm{hr}$ in the dark. Data represent mean \pm SD of three individual plants.
레스로 작용하고 있음을 확인할 수 있으며, 아스코브산 과산 화효소와 글루타사이온 환원효소(GR)가 작용하여 과산화수 소를 제거하기 위한 메카니즘이 발현된다고 하였다. 저온에 노출된 식물에서 저온에 적응하는 메카니즘은 카탈레이스나 수퍼옥사이드 전이효소뿐 만 아니라 아스코브산과 관련된 몇 가지 효소가 작용하는 것으로 생각할 수 있다[11,12,17,19].

\section{아스코브산과 디하이드로아스코브산의 함량변화}

아스코브산과 관련된 효소의 작용과 저온과 같은 스트레스 에 적응하기 위하여 생성되는 항산화물질인 아스코브산과 그 환원형인 디하이드로아스코브산과의 관련성을 확인하기 위 하여 저온에 노출되는 시간에 따라 생성되는 변화를 확인한 결과는 Fig. 2와 같다.

아스코브산의 함량 변화는 Fig. $1 \mathrm{~A}$ 에서 보는 바와 같이 저 온에 노출된 동안 거의 일정하게 증가하는 경향을 보였다. 그 러나 dehydroascorbate의 함량은 저온에 노출되는 동안 급격 히 감소하였다가 실온으로 회복되면 약간 증가하는 경향을 보였다. 식물에서 과산화수소를 무독화하는 과정은 아스코브 산과 관련된 일련의 효소가 작용하는 메카니즘으로 발현된다
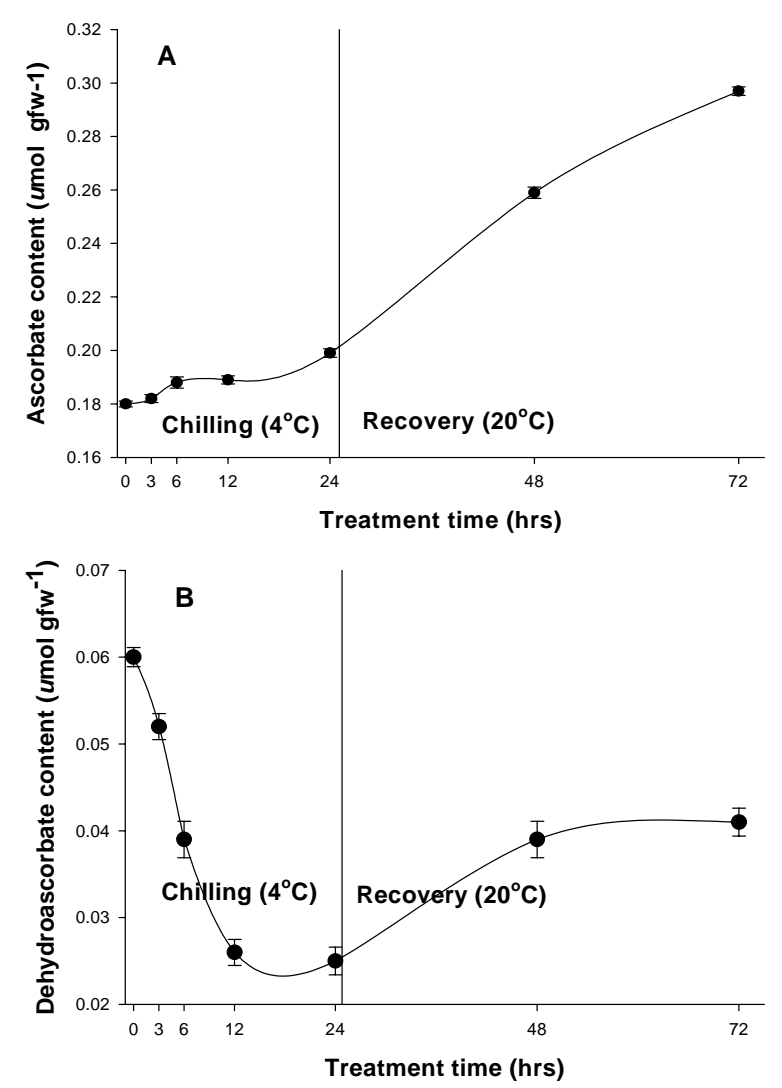

Fig. 2. Ascorbate (A) and dehydroascorbate (B) content in lettuce leaves subjected to low temperature stress. Cold treatments were performed at $4^{\circ} \mathrm{C}$ for $24 \mathrm{hr}$, and followed by recovery was performed at $20^{\circ} \mathrm{C}$ for $48 \mathrm{hr}$ in the dark. Data represent mean \pm SD of three individual plants. 
[24,25,26]. 식물은 변화하는 환경스트레스에 적응하기 위하여 아스코브산의 함량은 일정한 수준으로 유지되어야 하므로 아 스코브산의 재생과 관련된 효소의 활성이 증가함에 따라 아스 코브산과 디하이드로아스코브산의 비율이 일정해지는 것으 로 추정할 수 있다[2,5]. 상추식물의 경우 저온에 노출시켰을 때는 $\mathrm{MDHA}$ 환원효소의 활성도가 증가하다가 저온 스트레스 를 회복시키면 $\mathrm{MDHA}$ 환원효소의 활성도는 다시 감소한다 (Fig. 1). 상추식물의 잎 내 아스코브산의 함량은 급격하게 증 가되며(Fig. 2A), 이때 아스코브산의 재생과 관련된 다른 효소 가 작용한 결과라고 생각된다[12,13]. 따라서 아스코브산이 재 생되는 속도가 증가하면서 다하이드로아스코브산의 함량은 상대적으로 감소하는 것으로 생각된다(Fig. 2B). 엽채소류 내 항산화물인 아스코브산의 함량을 증가시키기 위하여 일정기 간 동안 저온에 노출시킨 후 적정온도로 회복시키면 그 함량 을 다소 증가시킬 수 있을 것으로 생각된다.

\section{$\mathrm{MDHA}$ 환원효소 활성도와 아스코브산, 디하이드로아스코 브산과의 상관관계}

아스코브산은 식물을 저온에 노출시켰을 때 이와 관련된 여러 효소들과의 상호작용으로 세포내 수준이 약간씩 증가하 면서(Fig. 2A) 식물이 저온에 대한 저항성을 획득하는 것으로 생각할 수 있다. 엽록체분획과 세포질분획에서 $\mathrm{MDHA}$ 환원 효소의 활성도 증가와 상추식물의 잎 내 아스코브산 또는 디 하이드로아스코브산의 함량 변화(Fig. 2B)와의 상관관계를 확 인한 결과는 Fig. 3 과 같다.

저온 처리를 한 상추의 잎 내 아스코브산의 함량은 0.180 $\mu \mathrm{mol} \cdot \mathrm{gfw}^{-1}$ 에서 $0.199 \mu \mathrm{mol} \cdot \mathrm{gfw}^{-1}$ 범위 내에 있었으며, 엽 록체분획과 세포질분획의 $\mathrm{MDHA}$ 환원효소의 활성도와의 상 관관계는 각각 비슷한 정의 상관 $\left(R^{2}=0.9240,0.9108\right)$ 을 나타내 어 식물체내에서 아스코브산의 함량과 $\mathrm{MDHA}$ 환원효소의 활 성도와 밀접한 관련을 가지는 것으로 생각된다(Fig. 3). 그러나 환원형인 디하이드로아스코브산의 함량과 $\mathrm{MDHA}$ 환원효소 의 활성도 사이에는 각각 더 강한 부의 상관 $\left(\mathrm{R}^{2}=0.8638,0.8980\right)$ 을 나타내었다(Fig. 4). 이 결과는 상추식물이 저온과 같은 스 트레스에 노출되었을 때 일차적으로 아스코브산 과산화효소 의 촉매작용으로 중간생성물인 MDHA가 생성되며, $\mathrm{MDHA}$ 환원효소가 중간생성물을 아스코브산으로 재생을 촉진시키 므로 $\mathrm{MDHA}$ 환원효소의 활성도와 아스코브산의 함량과는 정 의 상관을 가지게 되는 것으로 생각된다(Fig. 3). 이러한 경향 은 엽록체분획과 세포질분획에서 비슷한 경향(Fig. $3 \mathrm{~A}, \mathrm{~B})$ 을 가지므로 이 효소는 엽록체와 세포질에 존재하는 것으로 생각 된다. 반면 MDHA 환원효소의 활성도가 증가하면서 환원형 인 디하이드로아스코브산으로 환원되는 양이 감소하기 때문 에 $\mathrm{MDHA}$ 환원효소의 활성도와 $\mathrm{DHA}$ 의 함량과는 부의 상관 을 가지는 것으로 생각되며 이러한 경향은 아스코브산과의 상관관계와 연관을 가지는 것으로 생각된다(Fig. 4).
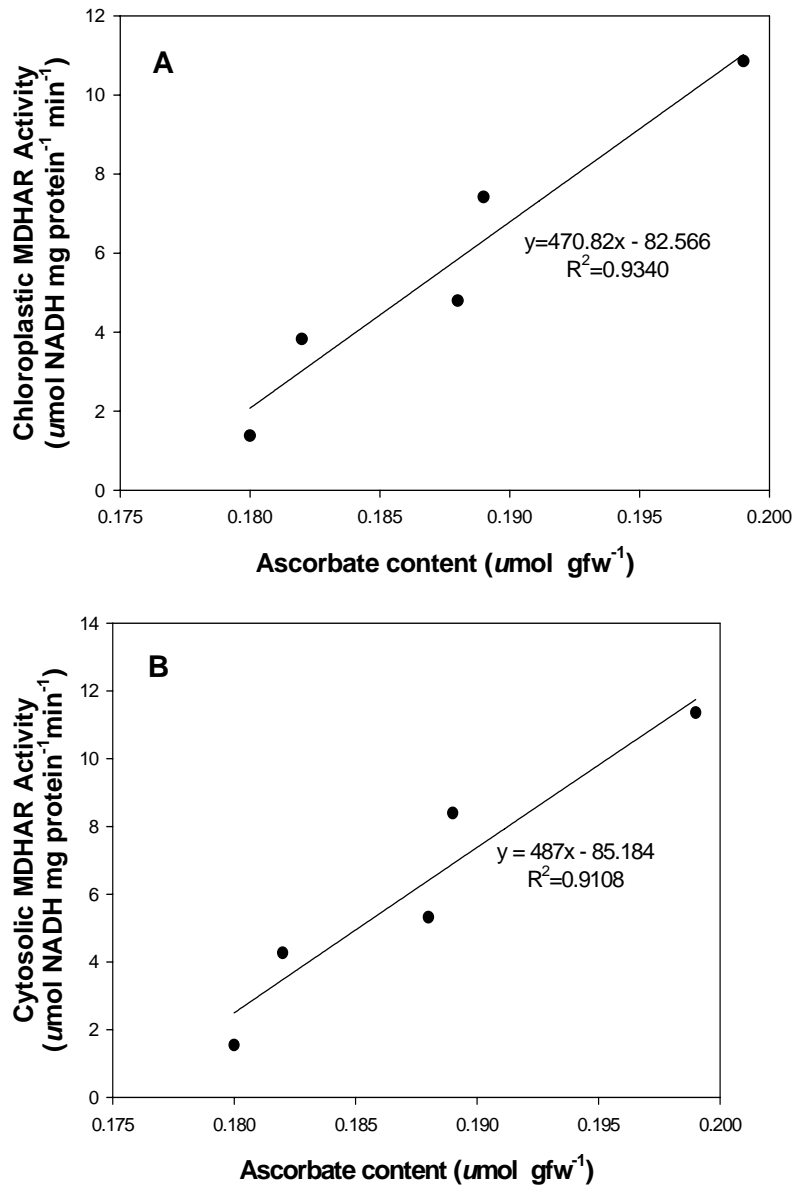

Fig. 3. Correlation between chloroplastic (A) and cytosolic MDHA reductase (MDHAR) activity (B) and ascorbate content in lettuce leaves as subjected to low temperature stress.

$\mathrm{MDHA}$ 환원효소 활성도와 과산화수소 생성량과 상관관계

저온은 식물에 산화적스트레스로 작용하므로 과산화수소 의 함량이 증가되므로[12,21], $\mathrm{MDHA}$ 환원효소의 활성과의 상관관계를 확인한 결과는 Fig. 5 와 같다. 엽록체분획과 세포 질분획 모두에서 과산화수소의 생성량이 증가하면 $\mathrm{MDHA}$ 환원효소의 활성도 각각 정의 상관 $\left(\mathrm{R}^{2}=0.9443,0.9647\right)$ 을 나 타내었다.

식물은 세포 내에서 생성되는 활성산소인 수퍼옥사이드(· $\mathrm{O}_{2}{ }^{-}$)는 엽록체 틸라코이드의 광계 I (photosystem I)에서 전 자수용체의 자동산화작용으로 생성되는 피할 수 없는 작용이 다. 수퍼옥사이드의 독성을 제거하기 위하여 일차적으로 수퍼 옥사이드 전이효소(SOD)가 작용하여 과산화수소로 환원되 고, 이 과산화수소는 일련의 효소적반응으로 물로 환원되는 과정을 가지는 시스템으로 진화되어 있다[2,25]. 이때 생성된 과산화수소는 아스코브산이 전자공여체로 작용하고 아스코 브산 과산화효소가 작용하여 물로 환원된다. 과산화수소를 무 독화하는 일련의 효소적작용에 관여하는 효소는 아스코브산 

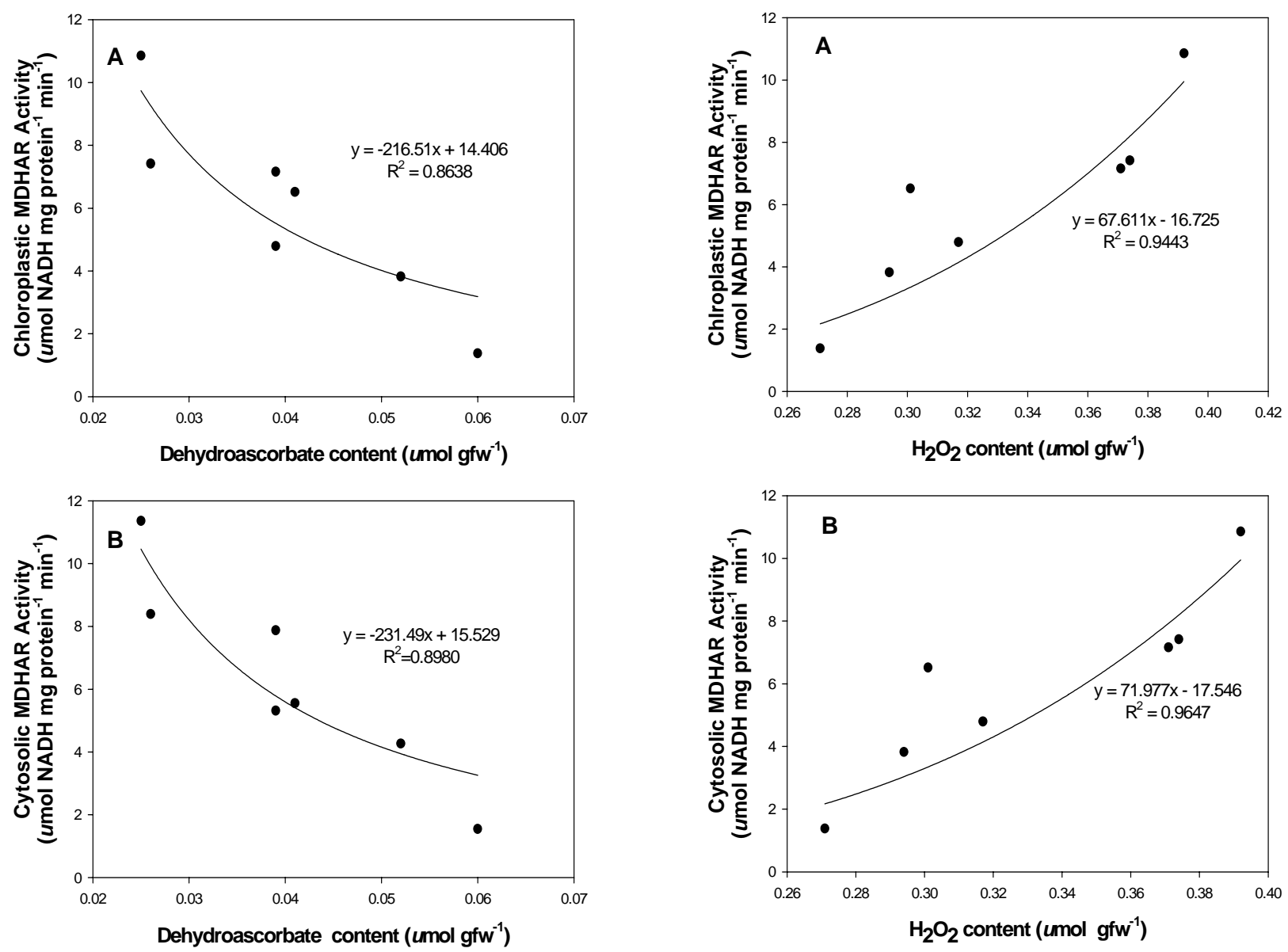

Fig. 4. Correlation between chloroplastic (A) and cytosolic MDHA reductase (MDHAR) activity (B) and dehydroascorbate content in lettuce leaves as subjected to low temperature stress.

과산화효소와 디하이드로아스코브산 환원효소 등이 관여한 다[2,9,12]. 이와 네트웍으로 연결된 MDHA 환원효소의 활성 도가 증가되어(Fig. 1) 과산화수소를 무독화하지만 식물체 내 과산화수소의 생성량은 계속 증가되어 정의 상관을 가지는 것으로 생각된다(Fig. 5). 이 결과는 수분부족스트레스를 처리 한 상추의 잎 내에서도 동일한 결과를 얻었으며[13], 오존처리 [13], 관수온도[15] 등에 대해서도 비슷한 결과를 보였다. 또한 시금치[19]와 토마토[7] 등 식물의 종류에 따라서 비슷한 경향 을 나타내는 것으로 보고되어 있다. Okuda 등[21]은 겨울밀의 잎에 저온처리를 하였을 때 과산화수소의 함량이 처리한 후 수분 내에 3 배 이상 증가하였으며 15 내지 20 분이 지나면 정상 수준으로 회복한다고 보고하였다. 그러나 상추식물에서 저온 처리 시간이 증가하면서 과산화수소의 함량이 점진적으로 증 가하였으며[12], 오이식물에서도 과산화수소의 함량이 증가하 는 경향을 나타내었다[17].

\section{$\mathrm{MDHA}$ 환원효소의 Northern Blot}

저온처리에 의한 상추의 잎 내에서 스트레스에 적응하는

Fig. 5. Correlation between hydrogen peroxide content and chloroplastic (A) and cytosolic MDHA reductase (MDHAR) activity (B) in lettuce leaves as subjected to low temperature stress.

메카니즘에 관련된 몇 가지 효소의 활성은 증가하는 경향을 보이며[12,17], 저온 스트레스를 처리한 경우 상추식물의 잎 내 MDHA 환원효소의 mRNA수준 변화를 Northern Blot 분 석으로 나타낸 결과는 Fig. 6과 같다. 저온스트레스 처리 시간 이 증가할수록 $\mathrm{MDHA}$ 환원효소의 활성도는 엽록체분획과 세 포질분획 모두에서 급격하게 증가하다가 저온을 회복시키면 활성도가 회복되는 결과를 보이고 있다(Fig. 1). 저온에 노출된 시간이 증가할수록 $\mathrm{MDHA}$ 환원효소의 mRNA의 발현 수준 도 증가하는 경향을 나타내고 있으며(Fig. 6A), 총 MDHA 환 원효소의 활성도가 저온에 노출되는 시간이 증가할수록 증가 하였다(Fig. 6B).

이 결과는 저온과 같은 환경에 노출되었을 때 식물의 저온 적응성의 획득에 관여하는 효소적과정에서 아스코브산과 연 관된 효소는 아스코브산 과산화효소와 디하이드로아스코브 산 환원효소와 더불어 $\mathrm{MDHA}$ 환원효소의 활성도 효소적과정 에 직접적으로 연관되어 있음을 확인할 수 있다. 따라서 상추 식물은 저온 스트레스에 노출되면 아스코브산의 재생과 관련 
A
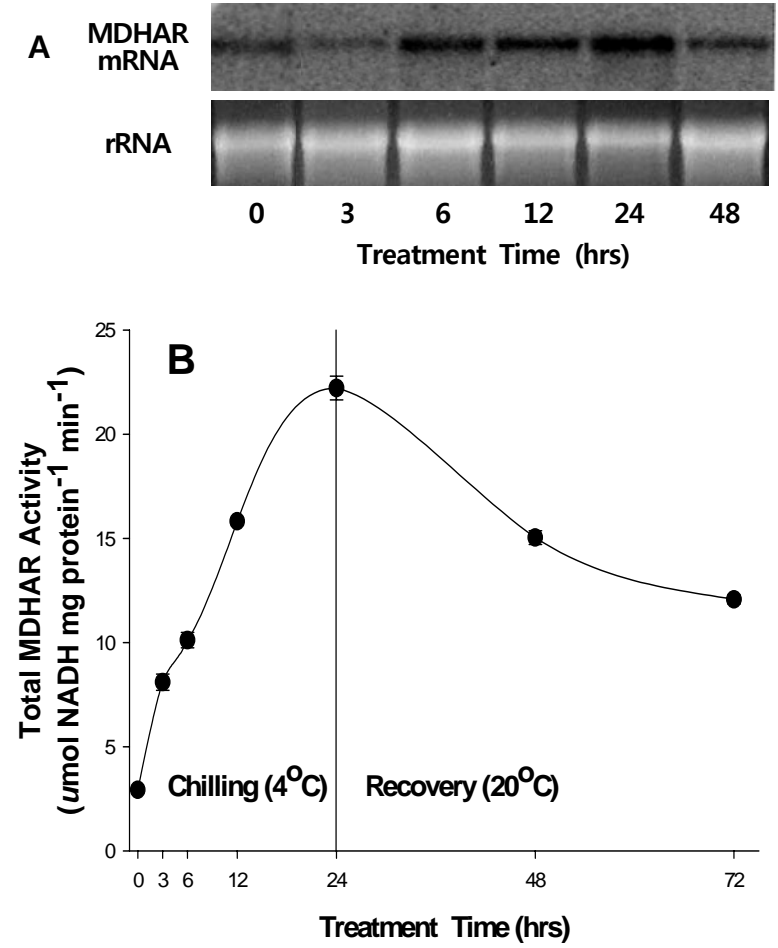

Fig. 6. RNA blot hybridization analysis for MDHA reductase mRNA. Total RNA was isolated from lettuce leaves subjected to low temperature stress, and separated by electrophoresis (11.4 $\mu \mathrm{g}$ each) for detection of MDHA reductase mRNA. MDHA reductase mRNA was detected by probing ${ }^{32} \mathrm{P}$-labeled single stranded MDHA reductase RNA. Total RNA on the agarose gel was stained with Ethidium Bromide (A). Total MDHA reductase activity in lettuce leaves subjected to low temperature stress. Cold treatments were performed at $4^{\circ} \mathrm{C}$ for $24 \mathrm{hr}$, and followed by recovery was performed at $20^{\circ} \mathrm{C}$ for $24 \mathrm{hr}$ in the dark (B). Data represent mean $\pm \mathrm{SD}$ of three individual plants.

된 $\mathrm{MDHA}$ 환원효소의 활성이 증가될 뿐만 아니라 $\mathrm{mRNA}$ 의 수준이 증가되어 환경조건에 적응하는 반응을 가지는 것으로 생각할 수 있다(Fig. 6A, B). 상추식물에서 수분부족 스트레스 와 같은 환경스트레스의 처리에서 $\mathrm{MDHA}$ 환원효소의 mRNA수준이 증가하는 경향을 보였다[13]. 저온처리에 의한 아스코브산 과산화효소와 디하이드로아스코브산 환원효소의 $\mathrm{mRNA}$ 의 수준이 효소의 활성도와 정의 상관으로 증가하는 경향을 보였으며[12], $\mathrm{MDHA}$ 환원효소의 mRNA 수준이 비슷 한 경향으로 증가하므로 이 세 가지 효소가 일련의 작용을 한다는 것을 추정할 수 있다[18,20,27].

\section{References}

1. Alexieva, V., I. Sergiev, S. Mapelli, and E. Karanov. 2001. The effect of drought and ultraviolet radiation on the growth and stress markers in pea and wheat. Plant Cell Environ. 24, 1337-1344.

2. Asada, K. 1994. Production and action of oxygen species in photosynthetic tissues, In Foyer, C. H. and P. M. Mullineaux (eds.), pp. 77-104, Causes of photooxidative stress and amelioration of defense systems in plants, CRC press Boca Raton, Fl.

3. Bradford, M. 1976. A rapid and sensitive method for the quantification of microgram quantities of protein utilizing the principle of protein-dye binding. Anal. Biochem. 59, 248-254.

4. Chang, S., J. Puryear, and J. Cariney. 1993. A simple method for isolating RNA from pine trees. Plant Mol. Biol. Rep. 11, 113-116.

5. Foyer, C. H., J. Rowell, and D. Walker. 1983. Measurements of the ascorbate content of spinach leaf protoplasts and chloroplasts during illumination. Planta 157, 239-244.

6. Foyer, C., H. Lopez-Delgado, J. F. Dat, and I. M. Scott. 1997. Hydrogen peroxide- and glutathione-associated mechanism of acclimatory stress tolerance and signalling. Physiol. Plant 100, 241-254.

7. Grantz, A. A., D. A. Brummell, and A. B. Bennett. 1995. Ascorbate free radical reductase mRNA levels are induced by wounding. Plant Physiol. 108, 411-418.

8. Heber, U., C. Miyake, J. Mano, C. Ohno, and K. Asada. 1996. Monodehydro- ascorbate radical detected by electron paramagnetic resonance spectrometry as a sensitive probe of oxidative stress in intact leaves. Plant Cell Physiol. 37, 1066-1072.

9. Hossain, M. A., Y. Nakano, and K. Asada. 1984. Monodehydroascorbate reductase in spinach chloroplasts and its participation in regeneration of ascorbate for scavenging hydrogen peroxide. Plant Cell Physiol. 25, 385-395.

10. Jiménez, A., J. A. Hernandez, L. A. del-Rio, and F. Sevilla. 1997. Evidence for the presence of the ascorbate glutathione cycle in mitochondria and peroxisomes of pea leaves. Plant Physiol. 114, 275-284.

11. Kang, H. M. and M. E. Saltveit. 2002. Effect of chilling on antioxidant enzymes and DPPH-radical scavenging activity of high and low-vigour cucumber seedling radicles. Plant Cell and Environ. 25, 1233-1238.

12. Kang, S. J. 2008. Response of ascorbate peroxidase and dehydroascorbate reductase in lettuce (Lactuca sativa L.) leaves exposed to cold stress. J. Life Sci. 18, 1705-1711.

13. Kang, S. J. 2008. Response of monodehydroascorbate reductase(MDHAR) in lettuce(Lactuca sativa L.) leaves subjected to water deficit stress. J. Bio-Environ. Control 17, 273-282.

14. Kang, S. J., J. Y. Oh, and J. D. Chung. 1999. Changes of antioxidant enzyme activities in leaves of lettuce exposed to ozone. J. Korean Soc. Hort. Sci. 40, 541-544.

15. Kang, S. J., J. Y. Oh, and J. H. Kim. 2001. Effect of temperature of irrigation water on the growth and activities of some enzymes in cucumber seedling (Cucumis satious L.). J. Korean Soc. Hort. Sci. 42, 399-404. 
16. Kim, T. S., S. J. Kang, and W. C. Park. 1999. Changes in antioxidant enzymes activities of soybean leaves subjected to water stress. J. Korean Soc. Agric. Chem. Biotechnol. 42, 246-251.

17. Lee, D. H. and C. B. Lee. 2000. Chilling stress-induced changes of antioxidant enzymes in the leaves of cucumber: in gel enzyme activity assays. Plant Sci. 159, 75-85.

18. Leterrier, M., F. J. Corpas, J. B. Barosso, L. M. Sandalio, and L. A. del Rio. 2005. Peroxisomal monodehydroascorbate reductase. genomic clone characterization and functional analysis under environmental stress conditions. Plant Physiol. 138, 2111-2123.

19. Morell, S., H. Follmann, M. D. Tullio, and I. Häberlein. 1997. Dehydroascorbate and dehydroascorbate reductase are phantom indicator of oxidative stress in plants. FEBS Letters 414, 567-570.

20. Murthy, S. S. and B. A. Zilinskas. 1994. Molecular cloning and characterization of a cDNA encoding pea monodehydroascorbate reductase. J. Biol. Chem. 269, 3112931133.

21. Okuda, T., Y. Matsuda, A. Yamanaka, and S. Sagisaka. 1991. Abrupt increase in the level of hydrogen peroxide in leaves of winter wheat is caused by cold treatment. Plant Physiol. 97, 1265-1267.

22. Sambrook, J., T. Fritsch, and F. Maniatis. 1989. Molecular cloning: A laboratory Manual, 2nd eds., Cold Spring Harbor Laboratory, Cold Spring Harbor, NY.

23. Sano, S., S. Tao, Y. Endo, T. Inaba, M. A. Hossain, C. Miyake, M. Matsuo, H. Aoki, and K. Saito. 2005. Purification and cDNA cloning of chloroplastic monodehydroascorbate reductase from spinach. Biosci. Biotechnol. Biochem. 69, 762-772.

24. Sato, Y., T. Murakami, H. Funatsuki, S. Matsuba, H. Saruyama, and M. Tanida. 2001. Heat shock-mediated APX gene expression and protection against chilling injury in rice seedlings. J. Exp. Bot. 52, 145-151.

25. Shigeoka, S., T. Ishikawa, M. Tamoi, Y. Miyakawa, T. Takeda, Y. Yabuta, and K. Yoshimura. 2002. Regulation and function of ascorbate peroxidase isoenzymes. J. Exp. Bot. 53, 1305-1319.

26. Yoshimura, K., Y. Yabuta, T. Ishikawa, and S. Shigeoka. 2000. Expression of spinach ascorbate peroxidase isoenzymes in response to oxidative stresses. Plant Physiol. 123, 223-233.

27. Yoon, H. S., H. S. Lee, I. A. Lee, K. Y. Kim, and J. K Jo. 2004. Molecular cloning of the monodehydroascorbate reductase gene from Brassica campestris and analysis of its mRNA level in respons to oxidative stress. Biochim. Biophys. Acta 1658, 181-186.

초록 : 저온 처리한 상추 잎에서 monodehydroascorbate 환원효소의 반응

강상재*

(경북대학교 생태자원응용학부)

식물의 저온 적응 메카니즘에서 아스코브산과 관련된 효소 중 $\mathrm{MDHA}$ 환원효소의 활성도와 과산화수소, 아스 코브산의 함량, $\mathrm{mRNA}$ 의 발현수준과의 연관성을 연구한 결과는 다음과 같다. $\mathrm{MDHA}$ 환원효소의 활성도 변화는 저온에 노출되는 시간이 길어질수록 증가하였으며 6시간 이후에 엽록체분획과 세포질분획에서 급격하게 증가하 는 경향을 보였으나 실온으로 회복시켰을 때 효소의 활성도가 상대적으로 감소하는 경향을 보였다. 저온에 노출 된 동안 아스코브산의 함량은 비교적 일정한 경향을 보이다가 실온으로 회복시키면 그 이후에는 급격하게 증가 하는 경향을 보였다. 반면 저온에 노출되는 동안 급격히 dehydroascorbate 함량이 감소하였다가 실온으로 회복 되면 약간 증가하는 경향을 보였다. 아스코브산의 함량과 엽록체분획과 세포질분획의 $\mathrm{MDHA}$ 환원효소의 활성도 와의 상관관계는 각각 정의 상관 $\left(\mathrm{R}^{2}=0.9240,0.9108\right)$ 을 나타내었으나 디하이드로아스코브산의 함량과 $\mathrm{MDHA}$ 환 원효소의 활성도 사이에는 각각 부의 상관 $\left(\mathrm{R}^{2}=0.8638,0.8980\right)$ 을 나타내었다. $\mathrm{MDHA}$ 환원효소 활성도와 과산화수 소의 함량과의 상관관계를 과산화수소의 생성량이 증가하면 $\mathrm{MDHA}$ 환원효소의 활성도가 증가하는 정의 상관 $\left(\mathrm{R}^{2}=0.9443,0.9647\right)$ 을 나타내었다. 저온스트레스 처리 시간이 증가할수록 $\mathrm{MDHA}$ 환원효소의 $\mathrm{mRNA}$ 의 발현 수 준과 총 $\mathrm{MDHA}$ 환원효소의 활성도가 증가하는 경향을 나타내었다. 